International Journal of Advancement in Life Sciences Research

Online ISSN: 2581-4877

journal homepage http://ijalsr.org

Review Article

\title{
The Implementation of Electronic Medical Record (EMR) in The Development Health Care System in Indonesia: A Literature Review
}

\author{
Nuke Amalia*, Muh. Zul Azhri, Anna Rosarini, Dina Ribka Wijayanti, Maya Ayu Riestiyowati \\ Sekolah Tinggi Ilmu Kesehatan Hang Tuah Surabaya, Gadungst. No. 1, Surabaya, 60244, Indonesia \\ ${ }^{*}$ Correspondence E-mail : nuke-amalia@stikeshangtuah-sby.ac.id
}

\begin{abstract}
The development of information technology is now growing rapidly, including in the health sector. According to WHO, medical record is an important compilation of facts about a patient's life and health. The development of information technology in medical records is the electronic medical record (EMR). Developed countries, such as the United States and Korea have implemented EMR for a long time. In developing countries such as Indonesia, the development of EMR is still in progress because its implementation requires many factors to build a system or replace from manual medical records. Eventually, it is hoped that in the future all health care will use the EMR to resume patient datas from admission to discharge. The purpose of this study is to analyse the implementation and preparation of EMR in health care in Indonesia. This study is a literature review on the implementation and preparation of EMR in health care in Indonesia. The review is dome from 28 literature sources (Google-Scholar database). Total of 8 articles were obtained from 2017 to 2021 . The results show that there are benefits after switching to EMR, even though some health care only used EMR in certain units. The highest benefit is reducing the cost of duplicating paper for printing. Also there is still limited human resources and tools for implementing EMR in Indonesia. The implementation of this EMR will enable the improvements of the service quality of the health care itself, especially in Indonesia.
\end{abstract}

Keywords: Implementation; EMR; Health care; Indonesia

\section{Introduction}

Medical records are files containing records and documents about patients identity, examination, treatment, other medical measures in health care facilities for outpatient, inpatient both government and private (Regulation of the Minister of Health Number 209 of 2008). According to WHO (2006), medical records are an important compilation of facts about a patient's life and health. PMK 269/2008 Regulation of the Minister of Health Number 269 of 2008 also stated that medical records must be made in writing, or electronically which must be complete and clear. This proves that in the future medical records will be developed electronically. Electronic Medical Record (EMR) is the development of information and communication technology in the field of health.

EMR has long been applied in developed countries, such as United States, Korea, China, England. In developing countries, EMR is still applied in some countries. Indonesia is a developing country where every health care centre does not implement EMR. Building EMR requires careful planning because its implementation requires involvement of many parties and they must be related and focused on the needs of users (Silvestre, 2018). RME 
Int J Adv Life Sci Res. Volume 4(3)08-12

in developing countries is very necessary to be developed, especially for Indonesia. Based on this statement, this study analyses the implementation and preparations of EMR by health care in Indonesia.

\section{Materials and Methods}

This research was a literature review. We searched sources including the Google
Scholar database (from 2017-2021). For downloading the research papers, we decided on search terms "Implementation" AND "Electronic Medical Record" in Indonesia's regions. In the early stages, we obtained 28 articles. These 10 articles are considered relevant. The articles were selected again according to the focus of the research, so finally 8 articles were obtained.

Table 1. Journal Resume

\begin{tabular}{|c|c|c|c|c|c|}
\hline No & Title & Author & Objectives & Methods & Results \\
\hline 1 & $\begin{array}{l}\text { Evaluation of Medical } \\
\text { Record Information } \\
\text { System in RSUD Kota } \\
\text { Surakarta to Supporting } \\
\text { Electronic Medical } \\
\text { Record }\end{array}$ & $\begin{array}{l}\text { Nugraheni } \\
(2017)\end{array}$ & $\begin{array}{l}\text { Evaluate the } \\
\text { management of } \\
\text { medical records in } \\
\text { hospital Surakarta } \\
\text { using an evaluation } \\
\text { model Health } \\
\text { Metrics Network } \\
(\mathrm{HMN})\end{array}$ & $\begin{array}{l}\text { Qualitative, } \\
\text { interview with } 3 \\
\text { respondents } \\
\text { (head of } \\
\text { medical record, } \\
\text { medical record } \\
\text { staff, and IT } \\
\text { staff }\end{array}$ & $\begin{array}{l}\text { Inadequate resources, } \\
\text { data sources but the } \\
\text { indicators SIM RS Pilar } \\
\text { Hospital is not yet fully } \\
\text { known as EMR }\end{array}$ \\
\hline 2 & $\begin{array}{lr}\text { Peningkatan } & \text { Mutu\& } \\
\text { Efisiensi } & \text { Pelayanan } \\
\text { Melalui Implementasi } \\
\text { Rekam Medis Elektronik } \\
\text { di RS Bethesda } \\
\text { Yogyakarta }\end{array}$ & $\begin{array}{l}\text { Saputro } \\
(2018)\end{array}$ & $\begin{array}{lr}\text { To know the } \\
\text { improvement } \\
\text { service quality }\end{array}$ & $\begin{array}{l}\text { Observational, } \\
\text { comparing } \\
\text { before and after } \\
\text { implementation } \\
\text { of EMR }\end{array}$ & $\begin{array}{l}\text { EMR increase the } \\
\text { quality objectives of } \\
\text { medical record } \\
\text { department, decrease } \\
\text { in cost health services }\end{array}$ \\
\hline 3 & $\begin{array}{l}\text { Analisis Strategi } \\
\text { Pengembangan Rekam } \\
\text { Medis Elektronik di } \\
\text { Instalasi Rawat Jalan } \\
\text { RSUD Kota Yogyakarta }\end{array}$ & $\begin{array}{l}\text { Pratama \& } \\
\text { Darnoto } \\
(2017)\end{array}$ & $\begin{array}{l}\text { Analyse the } \\
\text { development } \\
\text { strategies outlined } \\
\text { by EMR readiness }\end{array}$ & $\begin{array}{l}\text { Qualitative and } \\
\text { quantitative }\end{array}$ & $\begin{array}{l}\text { Yogyakarta General } \\
\text { Hospitals though a } \\
\text { strong organization but } \\
\text { faces many threats to } \\
\text { develop EMR }\end{array}$ \\
\hline 4 & $\begin{array}{l}\text { AnalisisKesiapanImple } \\
\text { mentasiRekamMedisEle } \\
\text { ktronikdenganPendekat } \\
\text { an DOQ-IT (Doctor's } \\
\text { Officer Quality- } \\
\text { Information Technology) }\end{array}$ & $\begin{array}{l}\text { Faida \& } \\
\text { Ali }(2021)\end{array}$ & $\begin{array}{l}\text { Analyse } \\
\text { readiness the } \\
\text { implementing RME } \\
\text { with the DOQ-IT } \\
\begin{array}{l}\text { approach at the } \\
\text { Surabaya } \\
\text { Hospital Haj }\end{array}\end{array}$ & $\begin{array}{l}\text { Quantitative, } 50 \\
\text { respondents }\end{array}$ & $\begin{array}{l}\text { Aspects of human } \\
\text { resources, } \\
\text { organizational, and } \\
\text { infrastructure aspects } \\
\text { are as a whole in a } \\
\text { ready category }\end{array}$ \\
\hline 5 & $\begin{array}{l}\text { Analisis Kebutuhan } \\
\text { Electronic } \\
\text { Record (EMR) Pasien } \\
\text { Rawat Jalan Dewasa } \\
\text { Menggunakan Metode } \\
\text { User Centered Design } \\
\text { (UCD) di RSCM }\end{array}$ & $\begin{array}{l}\text { Novitasari } \\
\text { et al } \\
(2020)\end{array}$ & $\begin{array}{l}\text { Analyse the needs } \\
\text { of } \\
\text { implementation }\end{array}$ & $\begin{array}{l}\text { Observational, } \\
\text { interview }\end{array}$ & $\begin{array}{l}\text { There are } 3 \text { needs for } \\
\text { users and } \\
\text { organizations, namely, } \\
\text { informational needs, } \\
\text { functional needs, and } \\
\text { non-functional needs }\end{array}$ \\
\hline 6 & $\begin{array}{l}\text { Resistor Factors of } \\
\text { Electronic Medical } \\
\text { Record Implementation } \\
\text { in Yogyakarta City } \\
\text { Hospital as a } \\
\text { Government-Owned } \\
\text { Hospital in } 2018\end{array}$ & $\begin{array}{l}\text { Syahputra } \\
\text { \& } \\
\text { Kurniawan } \\
(2018)\end{array}$ & $\begin{array}{l}\text { To determine the } \\
\text { inhibiting factors of } \\
\text { the application of } \\
\text { electronic medical } \\
\text { records with } \\
\text { fishbone analysis }\end{array}$ & $\begin{array}{l}\text { Qualitative, } \\
\text { interview with } \\
\text { medical record } \\
\text { officers, nurses } \\
\text { and doctors }\end{array}$ & $\begin{array}{l}\text { In terms of manpower, } \\
\text { some doctors feel } \\
\text { difficult. In methods, } \\
\text { there is no } \\
\text { continuation in the } \\
\text { proposed blueprint and } \\
\text { executive team. In }\end{array}$ \\
\hline
\end{tabular}




\begin{tabular}{|c|c|c|c|c|c|}
\hline & & & & & $\begin{array}{l}\text { terms of machine, } \\
\text { hospital management } \\
\text { information system } \\
\text { (HIS) does not support } \\
\text { this fully. In terms of } \\
\text { materials, the } \\
\text { application of HIS is } \\
\text { still being developed } \\
\text { by third parties }\end{array}$ \\
\hline 7 & $\begin{array}{l}\text { Pengembangan Rekam } \\
\text { Medis Konvensional } \\
\text { Menuju Rekam Medis } \\
\text { Elektronik di RS PKU } \\
\text { Muhammadiyah } \\
\text { Gamping Tahun } 2018\end{array}$ & $\begin{array}{l}\text { Purwanti } \\
\& \\
\text { Kurniawan } \\
(2018)\end{array}$ & $\begin{array}{l}\text { To know the groove } \\
\text { of procedure, } \\
\text { planning, } \\
\text { development, and } \\
\text { implementation of } \\
\text { conventional } \\
\text { medical records } \\
\text { towards electronic } \\
\text { medical records in } \\
\text { PKU } \\
\text { Muhammadiyah } \\
\text { Gamping Hospital }\end{array}$ & $\begin{array}{l}\text { Qualitative, } \\
\text { observations } \\
\text { and interview } \\
\text { with medical } \\
\text { records officers, } \\
\text { staff of IT, } \\
\text { doctors, and } \\
\text { nurses }\end{array}$ & $\begin{array}{l}\text { The development of } \\
\text { EMR is still ongoing } \\
\text { and the } \\
\text { implementation is } 90 \%\end{array}$ \\
\hline 8 & $\begin{array}{lr}\text { Evaluasi Rekam Medis } \\
\text { Electronik } & \text { Bagian } \\
\text { Coding Rawat Inap di } \\
\text { RSUD } & \text { K.R.M.T } \\
\text { Wonsonegoro } & \text { Kota } \\
\text { Semarang } & \end{array}$ & $\begin{array}{l}\text { Indrawati } \\
\text { et al } \\
(2020)\end{array}$ & $\begin{array}{l}\text { Evaluate EMR } \\
\text { implementation } \\
\text { using the PIECES } \\
\text { method } \\
\text { (performance, } \\
\text { information, } \\
\text { economic, control, } \\
\text { efficiency, services) }\end{array}$ & $\begin{array}{l}\text { Qualitative, } \\
\text { interview }\end{array}$ & $\begin{array}{l}\text { RME has already } \\
\text { produced } \\
\text { performance, can } \\
\text { provide accurate } \\
\text { information quality }\end{array}$ \\
\hline
\end{tabular}

\section{Results and Discussion}

The Implementation of Electronic Medical Record (EMR) in Indonesia's Health Care

Surakarta Government Hospital already has a computer-based medical record information system, hospital management information system (HIS) Pilar Hospital. HISin Surakarta Government Hospital information related to medical records are registration, inpatient, outpatient, emergency, laboratories, radiology, non-operative, pharmacy, and cashier. Pilar Hospital is desktop-based because it makes use of Microsoft Office, making it easy for all employees. Start page of Pilar Hospital uses security with username and password that must be filled up before entering the application. Officers have their own job description, so not all can fill in every module. Only two persons have access to all modules in HIS, IT and the head of medical records. The IT is responsible for the running of the system, including maintenance. The head of medical records is also given access because it relates to patient data thoroughly and continuously (Nugraheni, 2017).

Bethesda Yogyakarta Hospital is the oldest educational hospital and private hospital in Yogyakarta. Medical records documentation service in this hospital have not been fully carried out electronically. Eventually, this hospital claimed to have felt many benefits when medical records are electronically preserved. EMR activities are conducted electronically when the doctor writes history, treatment and diagnosis in the EMR module on the computer (Saputro, 2018).

EMR implementation at Government Hospital Dr. Cipto Mangunkusumo is targeted in 2020. Target users of EMR adult outpatients are doctors, nurses, medical recorders and pharmacists. Every user will be facilitated with tablet, stylus pen or computer. Adult outpatient EMR is built with security (username and password) connected databases stored on the 
server as a data center. Doctors can access patient profile, patient medical initial assessment, outpatient assessment and planning, integrated patient progress records, consultations, medical action approvals, outpatient and family information and education. Nurses can access integrated patient progress records pages, nursing assessments, of outpatient and family integrated patient and family information and education. The Medical recorders can access the patient's profile, make report of the top 10 outpatient diseases and reports of outpatient visits. Adult outpatient forms are in appropriate with the needs of users. This is because they created forms from every unit, so that the contents of the form correspond to the user. EMR is expected complete patient data can be recalled easily (Novitasari et al., 2020).

The procedures of conventional medical record at PKU Muhammadiyah Gamping Hospital was too long, while EMR has a shorter procedure. In June 2018 they were using two medical records, conventional and electronic. EMR was first used by a neurosurgeon in April 2018. The sectors involved in the development of EMR are management, directors, medical records, doctors, pharmacy, nurses, and IT. The implementation of EMR is carried out gradually. The trial was conducted from one doctor accompanied by conventional medical records near the computer (Purwanti \& Kurniawan, 2018).

Preparation of EMR in Indonesia's Health Care

The preparations of EMR include identification of the needs of medical records of the patients including information needs, functional needs and non-functional needs (Novitasari et al., 2020). Things to note in building EMR in the health service include identification of the elements, methods, machine, and materials.

The Advantages of EMR After Its Implementation

Health care that have used EMR partly, already feel some benefits. Saputro (2018) showed that in Bheteseda Hospital Yogyakarta the quality of the target medical records documentation for new patients that arrived at the clinic take less than 10 minutes and the old patient less than 20 minutes. Medical records documents complaints from nurses. So these EMR are cost savings in hospital due to the savings of paper and decreased storage needs.

The existence of computerized functions improves the effectiveness of the accuracy of input, storage, search, report, coordination between units and data transmission at Islamic Jemursari Hospital. EMR reduces file stacking time and form a centralized data storage. EMR reduces paper usage and save the cost of storage space and paper. The medical record system with RME can perform data retrieval faster, from 5-15 minutes for one patient to 36 seconds to use it (Irawan, 2019).

This is in line with Sudra (2020) that the use of EMR is expected to be able to produce quality documentation in medical records. It can support the need of healthcare for patients and service management and be able to produce information and reports. The EMR are beneficial in terms of efficiency, reliability, and care quality (Janet \& Yeracaris, 2020).

\section{Conclusion}

The implementation of EMR health care in Indonesia is still not fully used in all parts or units of the health care system. Identification of user, needs to be considered in building EMR, so that it can be constructed easily and interestedly. Although, some health care already feel the benefits of EMR implementation, the most advantageous effect felt by its users is the cost of savings. So, there is need for the development for EMR in health care in Indonesia. Mostly, the health care has been working with third parties in developing EMR. Hopefully health care system can develop their own EMR system in the future, which may help to solved many obstacles quickly.

\section{Acknowledgments}

The authors are thankful to Sekolah Tinggi IImu Kesehatan Hang Tuah Surabaya, Indonesia for supporting this research article.

\section{Conflicts of Interest}

The authors declare no conflict of interest. 


\section{References}

Faida, E. W., \& Ali, A. (2021). Analisis KesiapanImplementasi Rekam Medis Elektronik dengan Pendekatan DOQ-IT (Doctor's Office Quality-Information Technology). Jurnal Manajemen Informasi Kesehatan Indonesia (JMIKI),9(1): 67.

Indrawati, S. D., Nurmawati, I., Muflihatin, I.,\& Syaifuddin, S. (2020). Evaluasi Rekam Medis Elektronik Bagian Coding Rawat Inap RSUD K.R.M.T Wongsonegoro Kota Semarang. JREMI:Jurnal Rekam Medik Dan Informasi Kesehatan, 1(4): 614-623.

Irawan, I. (2019). Evaluasi Penerapan Sistem Rekam Medik Elektronik Berdasarkan Benefit Realization Plan RSI Jemursari Surabaya. Universitas Nahdlatul Ulama Surabaya (UNUSA).

Janett, R. S.,\&Yeracaris, P. P. (2019). Electronic Medical Records in the American Health System: challenges and lessons learned. Ciencia \& Saude Colectiva, 25(4): 1293-1304.

Novitasari, E., Santi, M. W., \& Deharja, A. (2020). AnalisisKebutuhan Electronic Medical Record (EMR) Pasien Rawat Jalan Dewasa Menggunakan Metode UCD di RSCM. J-REMI :Jurnal Rekam Medik Dan Informasi Kesehatan, 1(3): 297-310.

Nugraheni, S. W. (2017). Evaluation of Medical Record Information System in RSUD Kota Surakarta to Supporting Electronic Medical Record. Indonesian Journal On Medical Science, 4(1): 3343.

Pratama, M. H., \&Darnoto, S.(2017). Analisis Strategi Pengembangan Rekam Medis Elektronik Di Instalasi Rawat Jalan RSUD Kota Yogyakarta. Jurnal Manajemen Informasi Kesehatan Indonesia (JMIKI), 5(1): 34-45.
Purwanti, D., \& Kurniawan, A. (2018). Pengembangan Rekam Medis Konvensiona IMenuju Rekam Medis Elektronik di RS PKU Muhammadiyah GampingTahun 2018. Universitas Jenderal Achmad Yani Yogyakarta.

Saputro. (2018). Peningkatan Mutu \& Efisiensi Pelayanan Melaluilmplementasi Rekam Medis Elektronik di RS Bethesda Yogyakarta. Prosiding Seminar Nasional Rekam Medis \& Informasi Kesehatan Standar Akreditasi Rumah Sakit (SNARS) Edisi 1 Terkait Rekam Medis. 54-58.

Silvestre, E. (2018) How Electronic Health Records Strengthen the Health Systems of Low- and MiddleIncome Countries: Learning from Eswatini and Mexico. Chapel Hill, NC: MEASURE Evaluation, University of North Carolina.

Sudra, RI. (2020). Legal Certainty Regarding Electronic Medical Record Retention Period. International Proceedings The $2^{\text {nd }}$ Intertational Scientific Meeting on Health Information Management (ISMoHIM) 2020. 48-54.

Syahputra., Kurniawan (2018). Resistor Factors of Electronic Medical Record Implementation in Yogyakarta City Hospital as a Government-Owned Hospital in 2018. Universitas Jenderal Achmad Yani Yogyakarta.

World Health Organization. (2006). Electronic Health Records - Manual for Developing Countries. 